Reprod. Nutr. Dévelop., 1985, 25 (2), 389-397.

\title{
Intestinal absorption and secretion of total and lipid phosphorus in adult sheep fed chopped meadow hay
}

\author{
A. THÉWIS, E. FRANÇOIS $(*)$ \\ Faculté des Sciences Agronomiques de l'Etat, Chaire de Productions animales, \\ 5800 Gembloux, Belgium. \\ (*) Centre de Recherches Agronomiques de l'Etat, Station de Chimie et de Physique agricoles, \\ 5800 Gembloux, Belgium.
}

Summary. The flow of total $\left(P_{T}\right)$ and lipid $\left(P_{P L}\right)$ phosphorus was measured in adult sheep fed meadow hay and fitted with Ivan-Johnston reentrant cannulas in the duodenum (just posterior to the entry of the common bile and pancreatic duct) and in the terminal ileum. The pattern of plasma, duodenal and ileal $\mathrm{P}_{\mathrm{T}}$ and $\mathrm{P}_{\mathrm{PL}}$ specific radioactivity was also studied.

The considerable total and lipid $P$ secretion observed between the mouth and the duodenal cannula could be accounted for by salivary and biliary secretions, respectively. This secretion was followed by high absorption in the small intestine and less in the large intestine.

A comparison of $\mathrm{P}$ specific radioactivities showed that the selective $P_{\mathrm{PL}}$ reabsorption occurring in the small intestine could be due to the existence of an entero-hepatic cycle of biliary phospholipids.

\section{Introduction.}

Ruminant utilization of minerals can be studied by a wide range of methods. When phosphorus $(P)$ is investigated, these methods namely include regression and radioisotopic procedures for estimating endogenous loss and true availability, and in vitro and in vivo techniques for identifying gastrointestinal sites of mineral absorption and secretion. These techniques are often complementary.

Many workers have localized the gastrointestinal sites of $P$ absorption and secretion by using non-absorbable markers in slaughter experiments with sheep (Poppi and Ternouth, 1979; Théwis, François and Thielemans, 1978). Others have measured the flow of $P$ along the digestive tract of sheep fitted with intestinal cannulas (Bruce et al., 1966 ; Pfeffer, Thompson and Armstrong, 1970 ; Grace, Ulyatt and MacRae, 1974 ; Leibholz, 1974 ; Ben-Ghedalia et al., 1975).

On the other hand, several scientists have measured true $\mathrm{P}$ absorption while estimating endogenous $\mathbf{P}$ faecal excretion by the isotopic dilution method (Kleiber et al., 1951 ; Guéguen, 1962 ; Compère, 1966 ; Field, Munro and Suttle, 1977 ; Field et al., 1982 ; Braithwaite, 1981). This method is based on the assumption 
that $P$ secreted into the intestinal content has the same specific radioactivity as the $P$ of the blood plasma.

In a slaughter experiment using ${ }^{144} \mathrm{Ce}$ as an unabsorbable marker, we observed considerable total and lipid $P$ secretion in the duodenum of sheep, followed by absorption of the same order of magnitude in the jejunum and ileum (Théwis, François and Thielemans, 1978). Moreover, the specific radioactivity of $P$ in duodenal digesta was sometimes higher than that observed for plasma $P$ (François, 1974). If gastrointestinal $P$ secretions have a higher specific radioactivity than observed for plasma, their magnitude and the efficiency of endogenous $P$ absorption could affect the validity of results obtained by the isotopic dilution method.

In our previous paper, the amounts of $P$ secreted in the duodenum were higher than those reported in the literature and therefore questionable ; moreover, slaughter experiments have several drawbacks (Miller, 1972). In the present paper, the flow of total $\left(P_{T}\right)$ and lipid $\left(P_{P L}\right) P$ was measured in adult sheep fed meadow hay and fitted with Ivan-Johnston reentrant cannulas in the duodenum and the terminal ileum. The patterns of plasma, duodenal and ileal $P_{T}$ and $P_{P L}$ specific radioactivity were also investigated.

\section{Material and methods.}

Animals, diet and housing. - About 3 weeks before the experiments began, four Texel rams about 15 months old and weighing between 38 and $49 \mathrm{~kg}$ were fitted with reentrant Ivan-Johnston (1981) cannulas in the duodenum (just posterior to the entry of the common bile and pancreatic duct) and in the terminal ileum approximately $20 \mathrm{~cm}$ anterior to the ileocaecal junction.

The sheep received $907 \pm 33 \mathrm{~g} \mathrm{DM}$ /day of chopped meadow hay (particle size : $\max .5 \mathrm{~cm}$ ) and were fed hourly from an automatic device. Crude protein content was $10.9 \%$ (DM basis) and DM digestibility was 0.53 . Daily $P$ intake amounted to $2.16 \pm 0.28 \mathrm{~g} / \mathrm{sheep}$. The animals were adapted to the diet for at least 30 days before the experiment began.

${ }^{144} \mathrm{Ce}$ was used as an unabsorbable marker to correct the total 24-h flow of digesta through the reentrant cannulas. During the experiment, the hay was labelled with the radiomarker by spraying a solution of ${ }^{144} \mathrm{Ce}$ uniformly on the feed. After drying, we mixed the bulk of food required for each animal throughout the experiment. Further details are given elsewhere (François and Théwis, 1976). This process allowed strong adsorption of the ${ }^{144} \mathrm{Ce}$ on the hay particles, regular administration of the marker and uniform labelling of the digesta.

The animals were housed in metabolism cages with continuous lighting and had free access to water.

Experiment 1. - Five days before collection started, three sheep received hay labelled with radiocerium ; the fourth sheep was used as a digesta donor.

The experimental period included 4 days of total faecal collection followed by 48-h ileal collection and, about 2 days later, by 48 -h duodenal collection. 
The digesta were collected into Erlenmeyer flasks immersed in ice-water. Every $15 \mathrm{~min}$, an amount of digesta equivalent to that collected, coming either from the donor sheep or from previous collections, was warmed to $39{ }^{\circ} \mathrm{C}$ and gradually returned to the sheep. Every 2 or $3 \mathrm{~h}$, the digesta collected were weighed and mixed, and a $10 \%$ sample was taken for analysis. To obtain sufficient dry matter for subsequent analysis, aliquots from the duodenum were pooled over 8-h periods and those from the ileum over 6-h periods.

Experiment 2. - The same animals, diet and housing as in experiment 1 were used, except that the hay was not labelled. Four $\mathrm{mCi}$ of ${ }^{32} \mathrm{P}$ as $\mathrm{Na}_{2} \mathrm{HPO}_{4}$, dissolved in $2 \mathrm{ml}$ of neutral solution, were injected subcutaneously into sheep 1 and 2 , while sheep 3 received $12 \mathrm{mCi}$ of ${ }^{32} \mathrm{P}$.

On days 13, 14 and 15, intestinal digesta were collected for $11 / 2 \mathrm{~h}$ first from the duodenal and then from the ileal cannula. A subsample $(10 \%)$ was collected at about 15-min intervals and the remainder was gradually returned to the intestine. The aliquots were pooled daily. Just before ileal collection started, blood was taken from the jugular vein using iodoacetate-sodium heparinate as an anticoagulant. The plasma was separated by centrifugation and a trichloroacetic acid (TCA) filtrate of plasma was prepared immediately after collection. The samples were stored at $-20^{\circ} \mathrm{C}$.

Analysis. - All food, digesta and faeces samples were freeze-dried and then finely ground (1-mm sieve: Clyclotec mill). The lipids were quantitatively extracted from these samples by successively soaking them first in warm solvents (ethanol, chloroform and chloroform-methanol mixture ; $2: 1 \mathrm{~V} / \mathrm{V}$ ) and then in a cold chloroform-methanol nitric acid mixture (645:323:33 V/V/V). Lipid $P$ was estimated from the $P$ contents of the lipid extracts, (Théwis, François and Thielemans, 1978). The samples of food, faeces, digesta, urine and their respective phospholipid extracts, as well as blood TCA filtrates, were wet-ashed with a nitro-perchloric acid mixture $(2: 1 \mathrm{~V} / \mathrm{V})$. When necessary, the organic solvents were removed previously by evaporation.

$P$ was determined colorimetrically in the solutions according to the method of Misson (1908) using a Technicon autoanalyser. ${ }^{32} \mathrm{P}$ was measured with a gas flow counter after evaporation of a known amount of the solution in a plastic dish.

For ${ }^{144} \mathrm{Ce}$ counting, $0.5 \mathrm{~g}$ of dry food, digesta or faeces was thoroughly mixed with $4 \mathrm{~g}$ of non-radioactive ground faeces, $0.5 \mathrm{~g}$ of casein and a few drops of water. This mixture was shaped into hard discs using a laboratory press. The discs (about $8 \mathrm{~mm}$ thick) were counted with a gas flow counter.

Paired t-tests were used for statistical analysis.

\section{Results.}

Recovery of ${ }^{144} \mathrm{Ce}$ in digesta and faeces and flow of intestinal contents through the cannulas. - The recovery of ${ }^{144} \mathrm{Ce}$ in the digesta and faeces is shown in table 1 ; the mean daily recovery of the marker in the faeces largely exceeded $100 \%$. This might be due to the short collection period and/or to the occasional failure of the feeding system during the preexperimental period.

Reproduction Nutrition Développement, $n^{\circ} 2-85$. -4 . 


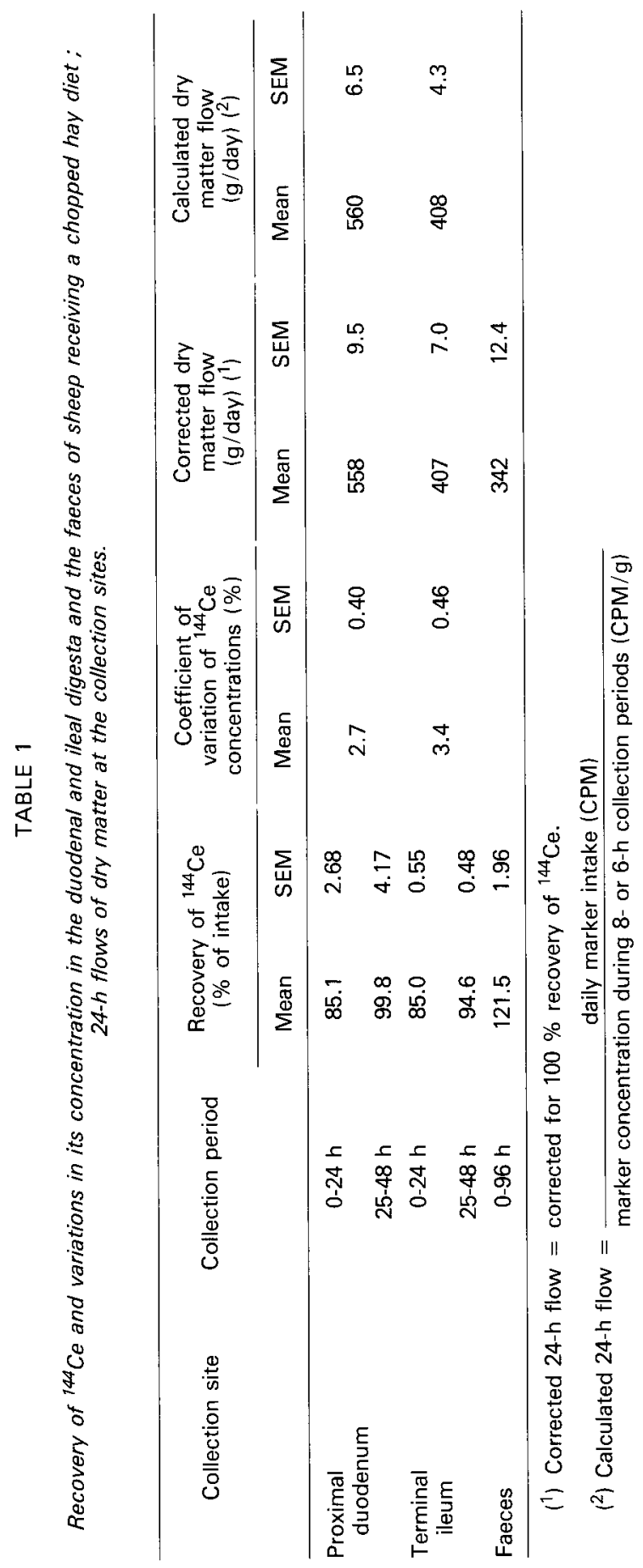


Table 1 also shows higher recovery of ${ }^{144} \mathrm{Ce}$ at the cannulas during the second 24-h period of collection.

Another important aspect of this experiment was the low variation in ${ }^{144} \mathrm{Ce}$ concentration in the duodenal and ileal digesta throughout the 6 or 8-h collection period, leading to calculated dry matter flows that were very close to the corrected values (table 1 ).

Flow of total $\left(P_{T}\right)$ and lipid $\left(P_{P L}\right) P$ along the digestive tract and net absorption and net secretion from and into various regions (table 2 ). - While virtually the same amounts of $P_{T}$ were excreted and ingested, the quantities of $P_{T}$ and $P_{P L}$ at the duodenal cannula were significantly higher $(P<0.01)$ than those in the diet and those leaving the ileum. This implies considerable net secretion of $\mathrm{P}_{\mathrm{T}}$ and $\mathrm{P}_{\mathrm{PL}}$ between the mouth and the junction of the common bile duct and duodenum, followed by net absorption from the small intestine. Although $\mathrm{P}_{\mathrm{T}}$ and $P_{\mathrm{PL}}$ faecal values were lower than the amounts leaving the ileum, the differences were significant only for $\mathrm{P}_{\mathrm{PL}}$.

TABLE 2

Flow and net absorption $\left({ }^{1}\right)$ of total $\left(P_{T}\right)$ and lipid $\left(P_{P L}\right) P$ along the digestive tract of sheep receiving a chopped hay diet.

\begin{tabular}{|c|c|c|c|c|}
\hline \multirow{2}{*}{ Item } & \multicolumn{2}{|c|}{$\mathbf{P}_{\mathrm{T}}$} & \multicolumn{2}{|c|}{$\mathrm{P}_{\mathrm{PL}}$} \\
\hline & Mean & SEM & Mean & SEM \\
\hline \multicolumn{5}{|l|}{ Amount, $\mathrm{mg} / 24 \mathrm{~h}$} \\
\hline In diet & 2161 & 28.3 & 84 & 9.1 \\
\hline Entering duodenum & 7280 & 270.3 & 384 & 7.6 \\
\hline Leaving ileum & 2935 & 60.2 & 123 & 10.0 \\
\hline In faeces & 2197 & 161.6 & 62 & 6.1 \\
\hline \multicolumn{5}{|l|}{ Net absorption ( $\left.{ }^{1}\right), \%$} \\
\hline Stomachs and proximal duodenum & -237 & 9.0 & -367 & 53.6 \\
\hline Small intestine & 201 & 7.7 & 320 & 48.0 \\
\hline Large intestine & 34 & 6.7 & 73 & 6.4 \\
\hline Whole gastro-intestinal tract & -2 & 6.2 & 26 & 1.1 \\
\hline
\end{tabular}

(1) Net absorption $=\frac{\text { absorbed }}{\text { ingested }} \times 100$

Specific radioactivity of plasma $P\left(S R P_{T C A}\right)$ and total $\left(S R P_{T}\right)$ and lipid $\left(S R P_{P L}\right) P$ at the duodenal and ileal cannulas. - In this experiment, duodenal and ileal collection was delayed by $2 \mathrm{~h}$; this roughly corresponded to the transit time of the digesta through the small intestine of the sheep. As shown in table 3, the $\mathrm{SRP}_{\mathrm{T}}$ was not different at the duodenal and ileal cannulas. Moreover, in all cases, $\mathrm{SRP}_{\mathrm{T}}$ at the duodenal site was lower than $\mathrm{SRP}_{\mathrm{TCA}}$. On the other hand, $\mathrm{SRP} \mathrm{P}_{\mathrm{PL}}$ decreased from the duodenum to the ileum, and $S R P_{P L}$ was very close to that of the plasma and sometimes higher. 
TABLE 3

Comparison of specific radioactivity of plasma inorganic $P\left(S R P_{T C A}\right)$, total $P\left(S R P_{T}\right)$ and lipid $P\left(S R P_{P L}\right)$ in the duodenal and ileal digesta of 3 sheep during 3 consecutive days after ${ }^{32} P$ injection (mean \pm SEM).

\begin{tabular}{|c|c|c|c|c|c|c|c|}
\hline \multirow{2}{*}{ Day } & \multirow{2}{*}{$\mathrm{SRP}_{\mathrm{TCA}}$} & \multicolumn{2}{|c|}{$\mathrm{SRP}_{\mathrm{T}}$} & \multirow{2}{*}{$\begin{array}{c}\text { Significance } \\
\text { of the } \\
\text { difference }\end{array}$} & \multicolumn{2}{|c|}{$\mathrm{SRP}_{\mathrm{PL}}$} & \multirow{2}{*}{$\begin{array}{c}\text { Significance } \\
\text { of the } \\
\text { difference }\end{array}$} \\
\hline & & Duodenum & lleum & & Duodenum & Ileum & \\
\hline 1 & 1 & $0.87 \pm 0.04$ & $0.86 \pm 0.06$ & N.S. & $0.97 \pm 0.01$ & $0.71 \pm 0.03$ & ** \\
\hline $2\left({ }^{1}\right)$ & 1 & $0.87 \pm 0.03$ & $0.86 \pm 0.04$ & N.S. & $0.98 \pm 0.06$ & $0.85 \pm 0.09$ & N.S. \\
\hline 3 & 1 & $0.86 \pm 0.02$ & $0.88 \pm 0.03$ & N.S. & $1.05 \pm 0.03$ & $0.82 \pm 0.04$ & $* *$ \\
\hline
\end{tabular}

N.S. : not significant $;^{* *}: \mathrm{P}<0.01$.

(') Only two sheep.

\section{Discussion.}

The Ivan-Johnston cannula (Ivan and Johnston, 1981) presents several advantages as compared with the Ash reentrant cannula (Ash, 1962) : (1) it does not involve transection of the intestine and (2) it provides representative samples of digesta without using a dual-phase marker. Moreover, it is easy to insert the cannulas, maintain the external part, and collect and reintroduce the digesta. Post-surgical recovery was rapid and the cannula was seldom blocked. Unfortunately, in our experiment, there was generally some leakage at the ileal cannula of the sheep about 3 months after surgery, and we could not keep the animals in good condition for more than $31 / 2-4$ months. Leakage appeared later at the duodenal cannula. At slaughter, we observed that the intestine had grown through the arterial prosthesis of woven dacron and was free of it. This was also reported by Poncet et al. (1982).

In spite of the fact that we used a regular feeding design and administered ${ }^{144} \mathrm{Ce}$ uniformly, faecal marker recoveries higher than $100 \%$ were observed (table 1). In previous experiments we had often noticed the irregular faecal excretion of the marker, especially when the animals were stressed or when the faeces were collected over a too-short period of 3 or 4 days. Generally, $100 \%$ recovery was only achieved over a 10 -day period. Since in this experiment neither the marker nor its administration were responsible for the irregular secretion, we adjusted the flow for $100 \%$ recovery of ${ }^{144} \mathrm{Ce}$.

On the other hand, the duodenal flow ranged from 13 to $63 \mathrm{~g} \mathrm{DM} / 2 \mathrm{~h}$, while the ileal flow varied from 26 to $57 \mathrm{~g} \mathrm{DM} / 3 \mathrm{~h}$. When the amounts of digesta collected were pooled over longer periods $6 \mathrm{~h}$ at the duodenal site and $8 \mathrm{~h}$ at the ileal site), the flow was more regular and variations in marker concentration in the digesta were rather low (table 1). Therefore, the flow of digesta could be calculated with good accuracy over 6 (duodenum) or 8 (ileum)-h periods (table 1 ).

As far as $P$ movement across the gut wall is concerned, we observed considerable net secretion between the mouth and the duodenal cannula. This agrees with the results of Pfeffer et al. (1970), Grace et al. (1974), Ben-Ghedalia 
et al. (1975), Théwis et al. (1978), Poppi and Ternouth (1979) and Ben-Ghedalia, Tagari and Geva (1982). The large amounts of saliva secreted continuously by the sheep and possible abomasal secretion explain this observation. From the results of Kay (1960), it may be calculated that if no $P$ absorption occurs before the small intestine, 3 to $8 \mathrm{~g}$ of $\mathrm{P}$ enter the rumen each day via the saliva. Moreover, in our experiment, $P$ from biliary phospholipids also contributed to the amount of $P$ entering the duodenal cannula. Adams and Heath (1963) calculated that $10-15 \mathrm{~g}$ of phospholipid or $0.4-0.6 \mathrm{~g}$ of $\mathrm{P}_{\mathrm{PL}}$ enter the sheep gut every day in the bile. The contribution of undegraded and ruminal endogenous phospholipids (Kurilov and Firsov, 1974) was not determined in this experiment.

The net absorption of $\mathrm{P}_{\mathrm{T}}$ in the small intestine reported in our experiment has also been mentioned by several other authors (Pfeffer et al., 1970 ; Ben-Ghedalia et al., 1975, 1982 ; Poppi and Ternouth, 1979 ; Grace et al., 1974 ; Théwis et al., 1978). Table 2 shows that $P_{P L}$ is largely absorbed in the small intestine. Unfortunately there is a lack of quantitative information on this subject in the literature. Lennox et al. (1968) reported the progressive disappearance of phospholipids through the intestine of sheep. Hydrolysed biliary phospholipids, together with bile salts, would help the micellar solubilization of fatty acids in sheep intestine and enhance the lipid absorption (Leat and Harrison, 1969, 1974 ; Harrison and Leat, 1972 ; Lough and Smith, 1976).

In our experiment, the amounts of $\mathrm{P}_{\mathrm{T}}$ and $\mathrm{P}_{\mathrm{PL}}$ secreted in the proximal duodenum were not as high as observed in a previous experiment with slaughtered sheep (Théwis et al., 1978) ; in the latter trial, they were probably due to excessive secretion of mineral and biliary organic $P$ at slaughter or to the sloughing-off of the epithelium during emptying.

Selective intestinal absorption of biliary phospholipids is also confirmed by the decrease of $S R P_{P L}$ from the duodenal to the ileal content. All these observations would suggest the existence of an entero-hepatic cycle of biliary phospholipids in sheep intestine similar to that found by Boucrot (1972) in rats.

The fact that $S R P_{\mathrm{PL}}$ at the duodenal site was sometimes higher than SRP $\mathrm{PCA}_{\mathrm{TCA}}$ may be explained by the biliary secretion. Indeed, specific radioactivity in the bile of sheep slaughtered 13 days after labelling with ${ }^{32} \mathrm{P}$ was higher than the value found in the plasma TCA filtrate (3.47 vs 2.78, respectively) (François, 1974). However, this observation does not alter the validity of the isotope dilution method of Kleiber et al. (1951), owing to the intestinal reabsorption of biliary phospholipids.

Reçu en janvier 1984.

Accepté en novembre 1984.

Acknowledgements. - This study was supported by grant $n^{\circ} 2.4521 .79$ from « Fonds de la Recherche Fondamentale Collective. »

Résumé. Absorption et sécrétion intestinales du phosphore total et phospholipidique chez le mouton adulte nourri au foin de prairie haché.

Le flux de $P$ total $\left(P_{T}\right)$ et de $P$ lipidique $\left(P_{P L}\right)$ est étudié chez 3 béliers adultes nourris au foin de prairie et munis de canules réentrantes au niveau du duodénum post-cholédoque et de l'iléon terminal. Chez ces mêmes animaux, on compare l'évolution des activités 
spécifiques du $\mathrm{P}$ plasmatique à celles du $\mathrm{P}_{\mathrm{T}}$ et du $\mathrm{P}_{\mathrm{PL}}$ au niveau duodénal et iléal. Les résultats montrent une sécrétion du $\mathrm{P}_{\mathrm{T}}$ et $\mathrm{P}_{\mathrm{PL}}$ entre la bouche et le duodénum. Si la première traduit un apport important de $P$ d'origine salivaire, la seconde doit essentiellement être attribuée à la sécrétion de phospholipides biliaires.

Cette sécrétion est suivie d'une absorption intense de $\mathrm{P}_{\mathrm{T}}$ et de $\mathrm{P}_{\mathrm{PL}}$ dans l'intestin grêle, voire même dans le gros intestin. L'évolution comparée des activités spécifiques de $\mathrm{P}$ plasmatique et de celles de $P_{\mathrm{T}}$ et de $\mathrm{P}_{\mathrm{PL}}$ au niveau du duodénum et de l'iléon traduit une absorption sélective du $\mathrm{P}$ lipidique ce qui pourrait s'expliquer par l'existence d'un cycle entero-hépatique des phospholipides biliaires chez le mouton.

\section{References}

ADAMS E. P., HEATH T. J., 1963. The phospholipids of ruminant bile. Biochim. biophys. Acta, 70, 688-690.

ASH R. W., 1962. Gastro-intestinal reentrant cannulae for studies of digestion in sheep. Anim. Prod., 4, 309-312.

BEN-GHEDALIA D., TAGARI H., ZAMWELL S., BONDI A., 1975 . Solubility and net exchange of calcium, magnesium and phosphorus in digesta flowing along the gut of the sheep. $B r . J$. Nutr., 33, 87-94.

BEN-GHEDALIA D., TAGARI H., GEVA A., 1982. Absorption by sheep of calcium, phosphorus and magnesium from a poultry litter supplemented diet. J. agric. Sci, Camb., 98, 85-88.

BOUCROT P., 1972. Is there an entero-hepatic circulation of the bile phospholipids ? Lipids, 7, 282 288.

BRAITHWAITE G. D., 1981. Effect of $1 \alpha$-hydroxycholecalciferol on calcium and phosphorus metabolism in sheep given high or low calcium diets. J. agric. Sci., Camb., 96, 291-299.

BRUCE J., GOODALL E. D., KAY R. N. B., PHILLIPSON A. T., VOWLES L. E., 1966 . The flow of organic and inorganic materials through the alimentary tract of the sheep. Proc. roy. Soc., $B, 166,46-62$.

COMPĖRE R., 1966. Utilisation du ${ }^{32} \mathrm{P}$ dans l'étude de l'action du niveau calcique de la ration sur le métabolisme du phosphore. II. Le mouton. Bull. Rech. agron. Gembloux, I (2), 190-227.

FIELD A. C., MUNRO C. S., SUTTLE N. F., 1977. Dried poultry manure as a source of phosphorus for sheep. J. agric. Sci, Camb., 89, 599-604.

FIELD A. C., COOP R. L., DINGWALL R. A., MUNRO C. S., 1982. The phosphorus requirements for growth and maintenance of sheep. J. agric. Sci, Camb., 99, 311-317.

FRANÇOIS E., 1974. La localisation de la résorption et de la sécrétion du phosphore dans le tractus digestif du mouton étudiée au moyen des radio-lanthanides. Th. Fac. Sci. agron. Gembloux, Belgium.

FRANÇOIS E., THEWIS A., 1976. Le radiocérium utilisé comme élément de référence dans le tractus digestif du mouton. Réalisation d'un marquage régulier. Bull. Rech. agron. Gembloux, $11(1-2), 87-100$.

GRACE N. D., ULYATT M. J., MacRAE J. C., 1974. Quantitative digestion of fresh herbage by sheep. III. The movement of $\mathrm{Mg}, \mathrm{Ca}, \mathrm{P} . \mathrm{K}$ and $\mathrm{Na}$ in the digestive tract. J. agric. Sci, Camb., 82, 321-330.

GUÉGUEN L., 1962. L'utilisation réelle du phosphore du foin de luzerne par le mouton, mesurée à l'aide de ${ }^{32}$ P. Ann. Biol. anim. Bioch. Biophys., 2, 143-149.

HARRISON F. A., LEAT W. M. F., 1972. Absorption of palmitic, stearic and oleic acids in the sheep in the presence or absence of bile and/or pancreatic juice. $J$. Physiol, 225, 565-576.

IVAN M., JOHNSTON D. W., 1981. Reentrant cannulation of the small intestine in sheep: cannula and surgical method. J. anim. Sci., 52, 849-856.

KAY R. N. B., 1960. The rate of flow and composition of various salivary secretions in sheep and calves. J. Physiol., 150, 515-537.

KLEIBER M., SMITH A. M., RALSTON N. P., BLACK A. L., 1951. Radiophosphorus $\left({ }^{32} \mathrm{P}\right)$ as tracer for measuring endogenous phosphorus in cow's faeces. J. Nutr., 45, 253-263. 
KURILOV N. V., FIRSOV V. I., 1974. Effect of fats and synthetic fatty acids on lipid metabolism in the rumen. Vestn. S-Kh Nauk, Moscow, 2, 62-67 (in russian) from Nutr. Abstr. Rev., 1975, 45, 4 (Abstr. $n^{\circ}$ 2051).

LEAT W. M. F., HARRISON F. A., 1969. Lipid digestion in the sheep : effect of bile and pancreatic juice on the lipids of intestinal contents. Q. J. exp. Physiol., 54, 187-201.

LEAT W. M. F., HARRISON F. A., 1974. Origin and formation of lymph lipids in the sheep. Q. J. exp. Physiol., 59, 131-139.

LEIBHOLZ J., 1974. The flow of calcium and phosphorus in the digestive tract of the sheep. Aust. J. agric. Res., 25, 147-154.

LENNOX A. M., LOUGH A. K., GARTON G. A., 1968. Observations on the nature and origin of lipids in the small intestine of the sheep. Br. J. Nutr., 22, 237-246.

LOUGH A. K., SMITH A., 1976. Influence of the products of phospholipolysis of phosphatidylcholine on micellar solubilisation of fatty acids in the presence of bile salts. Br. J. Nutr., 35, 89-96.

MILLER J. K., 1972. New techniques for intensive research with dairy cattle - Mineral research. J. Dairy Sci., 55, 1211-1219.

MISSON G., 1908, Kolorimetrische Phosphorbestimmung im Stahl. Chemiker-Zeitung, 32, 633.

PFEFFER E., THOMPSON A., ARMSTRONG D. G., 1970. Studies on intestinal digestion in the sheep. 3. Net movement of certain inorganic elements in the digestive tract on rations containing different proportions of hay and rolled barley. Br. J. Nutr., 24, 197-204.

PONCET C., IVAN M., LEVEILLÉ M., 1982. Electromagnetic measurements of duodenal digesta flow in cannulated sheep. Reprod. Nutr. Dévelop., 22, 651-660.

POPPI D. P., TERNOUTH J. H., 1979. Secretion and absorption of phosphorus in the gastrointestinal tract of sheep fed on four diets. Aust. J. agric. Res., 30, 503-512.

THÉWIS A., FRANÇOIS E., THIELEMANS M. F., 1978. Une méthode d'extraction quantitative des phospholipides totaux dans les aliments, les digesta et les fèces. Ann. Biol. anim. Bioch. Biophys., 18, 645-650.

THÉWIS A., FRANÇOIS E., THIELEMANS M. F., 1978. Etude quantitative de l'absorption et de la sécrétion du phosphore total et du phosphore phospholipidique dans le tube digestif du mouton. Ann. Biol. anim. Bioch. Biophys., 18, 1181-1195. 